\title{
Insights from pre-service teachers using science-based augmented reality
}

\author{
Julie A. Delello
}

Received: 30 August 2014/Revised: 25 October 2014/Accepted: 13 November 2014/

Published online: 30 November 2014

(C) Beijing Normal University 2014

\begin{abstract}
This research examined the results of an exploratory case study on the use of the augmented reality (AR) platform Aurasma in the higher education science classroom. Thirty-one pre-service students, enrolled in an undergraduate science methodology course, participated in the study. Research methods included data collection of teaching reflections regarding pre-service teachers' experiences using the platform Aurasma for learning. Findings included student perceptions regarding the usability of AR in the classroom setting and insights into how the Aurasma platform facilitated inquiry and understanding of science concepts. An analysis of the data suggested that AR has the potential to positively impact classroom learning experiences including an increase in motivation and engagement, teacher enthusiasm, and the facilitation of a community of practice. However, the incorporation of $\mathrm{AR}$ into the classroom was not without challenges, highlighting the fact that AR may be time consuming, teachers may not have the skills needed to use such technology, or there may be a lack of infrastructure. Each topic is discussed and supported by relevant literature and excerpts from the student reflections. Recommendations are given for future classroom implementation.
\end{abstract}

Keywords Augmented reality (AR) - Science · Pre-service teachers · Visual literacy · Virtual technology

A New York Times (2013) editorial recently stated that today's students are simply not interested in science, technology, engineering, or math, recognized as STEM. According to Dejarnette (2012), STEM programs have become a growing priority in American schools and efforts are continuing to introduce more STEM learning into existing P-12 curricula. Yet, the impact of high-stakes testing and issues related to teacher knowledge and staff development may hinder the process (Brophy 2008). In 
order to capture students' interests in STEM content, "a fundamentally different approach to teaching these subjects from childhood through high school" (New York Times 2013, para. 7) is needed.

Throughout history, science has been taught using a myriad of approaches. However, more recently, the infusion of science and technology has become essential for twenty first century learning. For example, the Next Generation Science Standards, as defined by the National Research Council (NRC 2012) represent a transformation in the way science is taught. Students will be required to read, write, and visually represent concepts through the development of models and explanations. According to the NRC (2013), students "will be asked to make decisions that influence the development of technologies and the direction of scientific research that we cannot even imagine today" (p. 6). Also, in the National Education Technology Plan, titled Transforming American Education-Learning Powered by Technology, The U.S. Department of Education (2010) reinforced the use of technology for learning in the following statement: "We must bring 21st century technology into learning in meaningful ways to engage, motivate, and inspire learners of all ages.... critical thinking, complex problem solving, collaboration, and multimedia communication should be woven into all content areas" (para. 6).

Consequently, it is important for teachers to engage their students in learning using an array of pedagogical and technological approaches. Prensky (2013) suggested that "teachers search for and use powerful uses of technology-things young people couldn't ever do before" (p. 1). Furthermore, technology is critical to science, because it allows the user to observe objects and phenomena that would otherwise be unable to be seen due to factors such as size, distance, location, and speed (NRC 1996).

\section{Literature review}

Classrooms are filled with students who are connected to image-rich technology. In this digital age, 13-17-year-olds spend an average of $3.1 \mathrm{~h}$ a day watching TV and $3.5 \mathrm{~h}$ using digital media (Oblinger and Oblinger 2005). A growing body of research supports the notion that today's students prefer teaching modalities that favor visual learning (Burmark 2002; Mayer and Gallini 1990; Peeck 1993; Powell and KusumaPowell 2011; Prensky 2001). According to Peeck (1993), the use of visual images in the classroom engages the learner, focuses their attention, and helps to simplify complex texts. Burmark (2002) remarked, "It's time for teachers to take advantage of the way kids entertain themselves today, to employ those same media and the thinking habits they foster for the betterment of student learning" (p. 3).

One emerging technology is augmented reality (AR) that merges the physical world with virtual images, graphics, and sound. In the Horizon Report, the New Media Consortium, NMC (2012) noted that AR has the potential to transform education. Using an iOS device such as a smart phone or iPad and an AR application (App), the user can create a 3D overlay that will augment based on a trigger image. AR allows the user to explore concepts that are otherwise impossible to see with the naked eye-making the unseen seen. In line with the constructivist 
theory of learning, an augmented environment moves from a teacher-centered environment to a learner-centered one where the students construct new information based upon their previous knowledge. By allowing students to have a more inquirybased approach to learning, they are able to create meaning and have a better understanding of complex scientific concepts.

Recent STEM-based research has attempted to ascertain how AR applications can be used in educational contexts. For example, Medicherla et al. (2010) used AR in the form of an interactive solar system to help middle school students grasp spatial concepts. Content lessons on digestive and circulatory systems (Pérez-López and Contero 2013), environmental science (Squire and Klopfer 2007), paleontology (National Science Foundation 2002), lunar phases (Tian et al. 2013), life cycles (Tarng and Ou 2012), animal transportation (Freitas and Campos 2008), and the modeling of chemical elements (Wojciechowski and Cellary 2013) have all shown enhanced learning through the use of AR applications. Also, AR was found to increase the comprehension of physics concepts including the visualization of micro-particles, which are too small to be seen with the unaided eye (Cai et al. 2013). Klopfer and Sheldon (2010) noted that AR enables "students to see the world around them in new ways and engage with realistic issues in a context with which the students are already connected" (p. 86).

Studies have also suggested that students have positive attitudes toward using AR for learning about science (Cai et al. 2013; Dunleavy and Simmons 2011). Moreover, AR applications not only improve students' knowledge of scientific content but may also help to eliminate common misconceptions (Shelton and Hedley 2004; Tian et al. 2013). For instance, Shelton and Hedley (2004) noted that the use of AR helped students to reduce the number of misconceptions in the relationship between the Earth and the Sun (e.g., solstice, seasons, rotation, and revolution).

Despite the potential of AR in enabling students to construct new understanding, the use of AR in education is just beginning to be explored (Cheng and Tsai 2013; Martín-Gutiérrez et al. 2010; Nunez et al. 2008; Sumadio and Rambli 2010) and according to Yoon and Wang (2014) "little is known about how the processes and interactions with the multimedia lead to increased learning" (p. 49). Also, recent research has shown that there is little evidence to determine whether AR improves conceptual understanding of science (Cai et al. 2013). Geroimenko (2014) noted that "there are therefore relatively few research materials available" (p. vii). Furthermore, Dunleavy et al. (2009) asserted that the literature is especially limited in regards to the issues facing teachers trying to integrate AR.

In this study, the use of AR was investigated in an elementary science methods course. The purpose of this research is an attempt to explore the perceptions of preservice teachers (PSTs) using AR tools in order to have a better understanding of how new technologies can be incorporated into teaching and learning. The following qualitative research questions were explored:

(1) What were PSTs' perceptions regarding the usability of the Aurasma tool for learning?

(2) How did AR facilitate student learning? 


\section{Methodology}

In order to explore the dynamics of using AR for teaching and learning, an exploratory case study approach was conducted in an undergraduate science methods course in the College of Education, at one regional 4-year university. Olsson and Salo (2012) noted that because the field of AR is still emerging, an explorative approach is required. According to Yin (2003), an exploratory case study involves examining situations in which the phenomenon being investigated has no clear, single set of outcomes. The case study, used as the research strategy, will allow a contribution to be made to the schools and universities interested in using AR and describe how to best support such emerging technologies in the classroom. Creswell (1998) noted that in order to build conceptual models for the future, a case study should provide a thorough description of the context, the processes observed, a discussion of the main findings, and the lessons to be learned.

\section{Setting and participants}

Participants for this study included 31 PSTs (29 female, 2 male) who were pursuing a bachelor's degree at a regional, 4-year university in the Southwestern US. Participants were in their third semester of a teacher educator program just prior to student teaching. The ethnicity of the participants was comprised of $74 \%$ White/ Caucasian American, $13 \%$ Hispanic, $9 \%$ Black/African American, and $4 \%$ Asian.

All participants were enrolled in a hybrid, undergraduate science methods course, which combined both online learning and face-to-face meetings. The purpose of the course was to provide prospective teachers with the opportunity to acquire scientific knowledge and methods of teaching science to early childhood—sixth grade students.

The PSTs were placed in field-based science classrooms where they prepared and taught a weekly lesson based upon content learned in the science methods course. To facilitate their learning outside the university, each soon-to-be teacher had a cooperating mentor teacher to help guide their teaching activities.

\section{Project description}

As part of a course project, the PSTs were asked to create a minimum of one science-based AR image using the free studio version of the platform Aurasma (https://studio.aurasma.com/register). Aurasma (www.aurasma.com), created by the software company Autonomy in 2011, uses advanced image and pattern recognition to detect an image in much in way the human brain does (Haymarket Media Group Ltd. 2012). Interactive content can be merged with images, sound, videos, and animations called "auras." For example, using the Aurasma App on an iOS or Android device, the "What's your Aura" image (see Fig. 1) comes to life.

AR was modeled by the professor halfway through the course, and a Facebook group was created for the PSTs to post information and share ideas on how to create AR images. Additionally, the PSTs met once in a face-to-face session and were offered the opportunity to participate in several online virtual conferences through 
Fig. 1 What's your aura (C)2013Aurasma. Used with permission

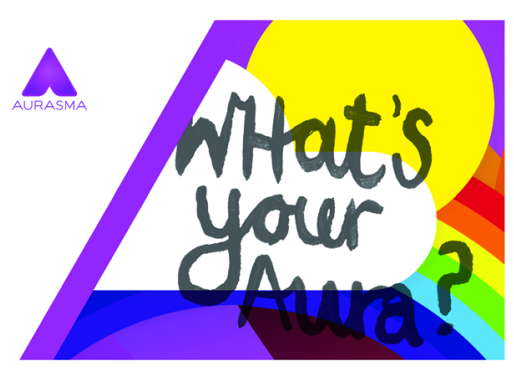

Turn Images into Auras with Aurasma Studio

Step One. Register online to receive an account for the Aurasma Studio.

Step Two. Upload a Trigger Image. Your image or an object as your Trigger Image, upload a PNG or JPEG file with no more than 500,000 pixels (width $x$ height).

Step Three. Upload an Overlay

Overlays can be images, videos, 3D scenes or models.

Formats include: MP4, FLV, PNG, JPEG and .TAR (3D)

Step Four. Create a Channel

Channels are like folders and contain collections of Auras. Give your Channel a relevant name, description and image. You need to set your Channel to 'Public'.

Step Five. Create an Aura

Add your Overlay to your Trigger Image and select any actions or commands. Name your Aura and place it in a Channel. Don't forget to add a URL for click- through website links.

Note: There is a "help" guide to walk you through each step located at: http://www-cdn.aurasma.com/wpcontent/uploads/Aurasma-Partner-Guidelines.pdf

Fig. 2 How to create an aura with Aurasma

the platform Zoom (Zoom.com). Specifically, students were given 4 weeks to complete the following requirements:

(1) Use the platform Aurasma to create an aura (hidden digital content) based upon elementary scientific content (see Fig. 2). 
(2) Submit your aura to your instructor using the project template provided on the course website. Make sure your aura is public and includes the channel name and link on the template.

(3) Integrate the aura into an inquiry-based lesson plan and teach the lesson in field.

(4) Complete a self-reflection on your teaching experience relevant to using AR as a means to learn science.

Data collection and analysis

Data were gathered retrospectively from 31 reflection papers collected in the spring of 2014. The student-teacher reflections on the use of AR were examined, and statements specific to using AR were extracted, entered verbatim, and coded independently by the researcher and a graduate assistant, trained in qualitative methodology.

The researcher and assistant discussed the coding and compared the emerging patterns until consensus was reached. All of the coding was done by hand in order to determine meaningful categories and themes. As a process of data reduction, the analysis looked for patterns in the data. Also, as Creswell (1998) suggested, the exact wording from participants was woven into the narrative passages. To show a "confirmability" of the research, as advised by Lincoln and Guba (1985), an audit trail of "raw data, analysis notes, reconstruction products, personal notes, process notes, and preliminary development information" (p. 320) was used. To assure confidentiality, all of the participant identifiers were removed and Institutional Review Board consent was obtained prior to the study. The conceptual themes, subthemes, and student responses of using AR to facilitate learning are presented in the findings.

\section{Findings}

RQ1: "What were pre-service teachers' perceptions regarding the usability of the Aurasma tool for learning?"

This study revealed that almost all (87\%) of the PSTs reported having few usability (ease of use) problems with the Aurasma platform. In fact, students reported Aurasma to be simple, easy to understand, and impressive. One prospective teacher conveyed, "Not only is augmented reality amazing, it's also free and easy to do." Additionally, all but one of the PSTs (97 \%) remarked that they liked the Aurasma tool and planned to continue using it. One student wrote, "I really liked this project and look forward to making more Aurasma images." A second conveyed, "I would like to continue to use this program... I need to make them better every time." 
In reality, the PSTs stated that the more they used the AR platform, the more confident they felt. For example, one student noted, "Once I got the hang of making the auras, I didn't want to stop." Another student wrote:

I hated this project to begin with, it was complicated and frustrating. After playing around with it for a couple weeks I finally got the hang of it and now I would love to use this in all my lessons.

A third student reflected on their own use of technology in the following excerpt:

It is not easy to learn something new, especially something that is technology related. I am not good at learning this technology. I am also stubborn and don't want anyone else's help. As a new teacher I am quickly throwing that idea away. If I would have gone and got help, this would have been a breeze.

Although many of the PSTs experienced the complexity of the technology, as corroborated by the research findings of Dunleavy and Dede (2013), they also pointed out that the more they used the technology, the more proficient they became at creating the auras.

RQ2: "How did AR facilitate student learning?"

In regards to student learning, three major themes strengths, challenges, and future use and six subthemes motivation and engagement, teacher acceptance, teacher rejection, time, technology, and a community of practice $(\mathrm{CoP})$ emerged from the data.

\section{Strengths}

Evidence points to the use of AR as an effective teaching methodology that not only engages students (Klopfer and Sheldon 2010) but also increases students' motivation to learn (Pérez-López and Contero 2013). The findings illustrate that PSTs perceived the use of AR to be both motivating and engaging to students (see Table 1). The reflections used the words amazed $(n=30)$, excited $(n=22)$, and attention getting ( $n=10)$ to describe the enthusiasm in the classroom.

According to one prospective teacher, "The [classroom] students' reactions to the AR project were a combination of surprise, questions, laughter, and hint of skepticism." Another pre-service student remarked, "It was a very awesome 'teacher' moment watching their reactions as the overlay popped out of the trigger image... I thought my Aurasma was very basic but the students thought it was the coolest thing in the world!"

In terms of student learning, the PSTs reported that AR motivated students to learn the content taught in class. In fact, $68 \%(n=21)$ of the PSTs documented in their reflections specifically how they perceived the use of AR in helping students learn science (see Table 2). For instance, one PST stated, "The students were fully engaged and they performed extremely well on the assessment at the end of the lesson."

Another PST noted, after viewing the aura, the class "actually listened to the video and made a connection to what the video was promoting." 
Table 1 Strengths of using AR for student learning

\begin{tabular}{ll}
\hline Strengths & Selected student extracts \\
\hline $\begin{array}{l}\text { Motivation and } \\
\text { engagement }\end{array}$ & - A neat feature about the AR is that it aroused student's attention longer about \\
the lesson and triggered more thoughtful questions about the concept \\
- Class participation was at an all-time high \\
- There is one student in the classroom that is inclusion and that student even \\
performed higher than she regularly would \\
- I used the aura in a small group lesson with students who are typically \\
troublemakers... When I showed them the aura, they said "awesome!" \\
- She was really impressed. She had never even heard of this before. After seeing \\
the student's reaction to it and seeing how much they liked it, she said she was \\
going to use this in her future lessons \\
- She was also amazed how interested the students were. I saw her the next week \\
while she was substituting first grade and she told me she had made an aura \\
over the basic body parts for review with her students \\
- It helped to let them experience Aurasma in small groups \\
Community of \\
practice
\end{tabular}

Table 2 Perceptions of learning

\begin{tabular}{lc}
\hline AR for learning & Number of reflections \\
\hline AR video explained the concept that was being taught & 11 \\
Aura's features motivated students to memorize concepts & 1 \\
Students were able to align the lesson with real life & 2 \\
Activity helped them learn & 3 \\
Students asked more questions & 2 \\
Performed better on assessments & 2
\end{tabular}

A different prospective teacher taught the concept of the rotation of the Earth to a kindergarten class. As part of the engagement piece of a 5E Lesson Plan, the PST dressed in overalls, house shoes, and a straw hat. In addition, she held a stuffed animal and The Night before Christmas story book. The class was learning to identify objects that one would use or see when the Sun is up (day) and when the Sun is down (night). After the lesson, the PST created an infographic for the trigger image combined with a video overlay of the children listening to the lesson she had taught (see Fig. 3).

In describing the reaction of the children to the playback of the lesson, the PST composed the following sentiment:

They loved seeing themselves on the screen after they got over the fact that it was coming from a picture. They would look at the iPad screen and then try and look around at the image to see if it had changed. This project made me hunger more for technology to be placed in the classroom for our students. Kindergarten students need engaging activities to keep them on task (learning). 
Fig. 3 Night and day

kindergarten aura (http://auras. $\mathrm{ma} / \mathrm{s} / \mathrm{vMoWZ}$ )
Fig. 4 Earth Day 2014 aura (http://auras.ma/s/0NaUl)
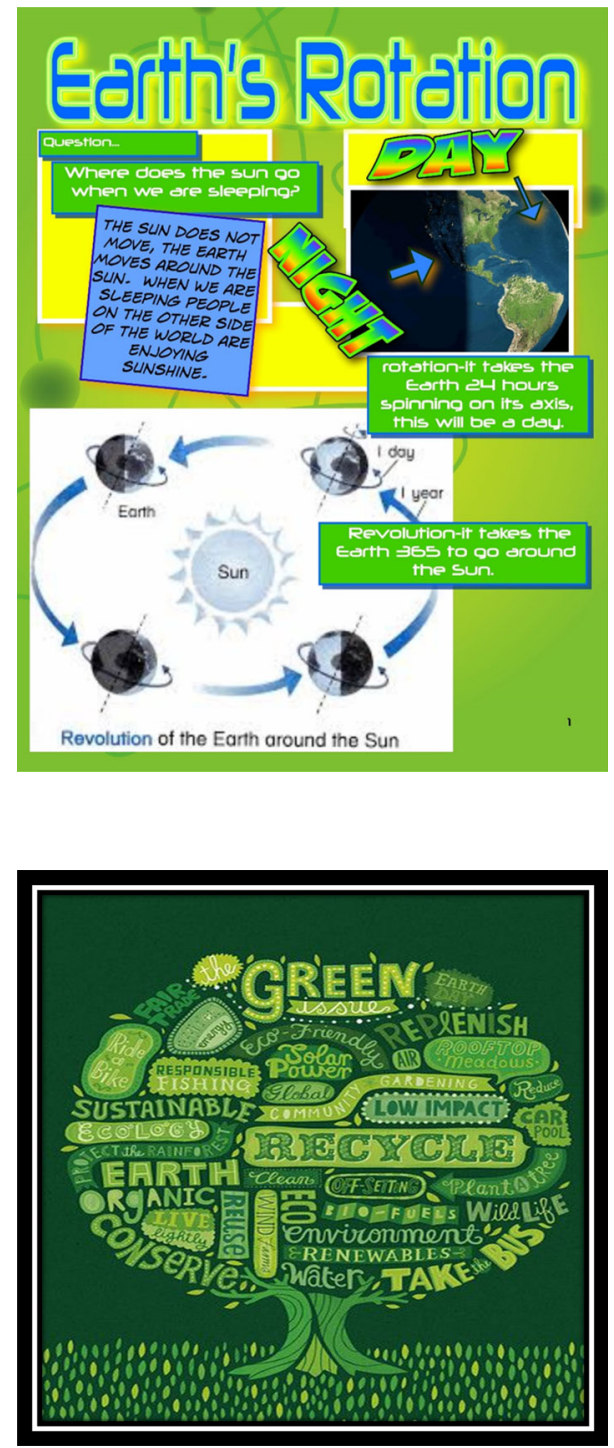

In another example, a lesson on "going green" was used to illustrate how AR motivated 30 fifth grade students to ask more content-related questions (see Fig. 4).

The PST noted, "This particular Aura was used as a conversation starter to brainstorm, promote, encourage, and apply the following Earth Science concepts: Earth Day, five major alternative energy sources, renewable and non-renewable energy, and long-and-short-term effects energy has on our planet." Also,

After we read our book and talked about recycling and did interactive writing about energy, we started talking about the effects the actions of humans 
sometimes have on the earth and what we can change to make it better. I, then, put the trigger image on the Smart Board, had them hold up the iPad, and wired the video to the Apple TV. They were in shock and started asking tons of questions... How did that picture come alive? Was it because of the word recycle?" My favorite statement was, "You just recycled...you put the video in the picture so that the TV didn't have to go and find it and use more electricity.

Supporting the findings of Lawless and Pellegrino (2007), the use of AR generally seemed to allow the PSTs to adopt better approaches to instruction, resulting in improved learning, instruction, and assessment for the classroom students.

\section{Teacher acceptance}

An additional strength of using AR was the impact it had upon the students' cooperating or mentor teachers. The majority of PSTs $(94 \% ; n=29)$ perceived their mentor teachers to be excited about the potential of AR. One prospective teacher revealed, "From the time I showed [my mentor] this, she has used (and created without my help) Aurasma three times in her class, and her principal used it in their school-wide after-school meeting." Another prospective teacher wrote, "[My mentor] was also amazed. She still struggles with how to calibrate her Smart Board so this really blew her away."

\section{Community of practice}

This study also demonstrated that AR may facilitate a CoP. Wenger et al. (2011) described a $\mathrm{CoP}$ as a "learning partnership among people who find it useful to learn from and with each other" (p. 9). In this study, students reflected that the use of AR allowed them to share ideas and learn through social interactions. For example, one PST noted the importance of group collaboration in the following statement: "They loved being in their groups and working together." However, using AR in a group also evoked a sense of competition as highlighted in the following excerpt: "There were a couple of arguments on who was going to get to go next." Also, such innovative uses of technology may motivate teachers to learn from one another as stated in the following reflection:

This was probably my favorite part of the whole day. Other teachers would walk a little slower by the room when they realized that ALL of the technology was being used at one time. Pre-K and Head Start thought I had lost the last of my marbles for letting all of them [the students] have an iPad at their table at one time...until they realized how neat it was.

Challenges to using AR

Ditzhazy and Poolsup (2002) asserted that both external (lack of access) and internal barriers (fear) may impact the integration of technology into classrooms. Also, Rogers (2000) contended that there are both internal barriers (perceived competency) 
and external barriers (e.g., tools, training, and support) to using technology. In this study, three challenges to using AR in the classroom emerged: Teacher rejection, teacher time, and technology limitations.

\section{Teacher rejection}

As new technologies emerge, many educators are often excited to find ways to incorporate these technologies in their classrooms (Courts and Tucker 2012). And, although the data showed that teacher acceptance of AR was perceived as primarily positive, two (7\%) student reflections documented that the mentor teachers thought the technology to be too much work or would create possible disruptions to the class. For example, one pre-service student wrote, "My mentor teacher was not as excited about it as I thought she would be... it was too much work." Another student reflected that the mentor teacher "hoped the AR wouldn't create chaotic noise and cause a negative shift in classroom management." Christensen et al. (2008) conveyed that when technology is seen as a disruptive innovation or rejected as established in this study, there is a critical need to re-evaluate the way that teachers develop and deliver instruction.

\section{Time}

Rogers (2000) asserted that challenges to using new technology tools is often due to a lack of time it takes to learn something new. In this study, the second subtheme of time was apparent. Three $(10 \%)$ prospective teachers noted their mentor teachers didn't think they had the time to understand and implement AR. One PST wrote [My mentor] "seemed to hint that there really wasn't a lot of time left for science."

\section{Technology limitations}

Although the majority (97 \%) of PSTs felt that using AR was beneficial to students, there were challenges to using AR applications in the classrooms. These barriers primarily dealt with the available technology. For example, the PSTs reflected that in some classrooms, the Wi-Fi was not strong enough to support the technology and there was a lack of sufficient devices (iPads, iPods, and headphones) to enable the students to view the auras. For instance, one prospective teacher noted, "I would like for each student to have their own iPad or iPod so that they can view the aura individually." Another student reflected, "Next time I would like to have more than one iPad so all of the students could see the Aura and not have to all look through one iPad." Additionally, a student commented:

I do not have an iPhone, iPad, or any device for this project. I will not use this project in my classroom or outside the classroom because most schools do not have the devices for this project to be used and some students will not have these devices to complete this project at home.

Another prospective teacher penned a thought-provoking statement, "I think the reason that more teachers are afraid of these kinds of things is because they have no 
idea what to do with them or proper training on how to create and use them." This theme is consistent with the literature, in that often times, educators lack confidence in technology especially in regards to dealing with probable equipment failures or slow Internet access (Moeller and Reitzes 2011).

\section{Future use}

When the PSTs were asked to provide a reflection on what they would do differently the next time they used AR, 21 (68\%) of the PSTs noted including the use of more advanced images and videos $(n=3)$, going deeper with the scientific concepts $(n=12)$, engaging students prior to the lesson with the aura $(n=1)$, introducing the concept before showing the aura $(n=2)$, and allowing students to create their own auras $(n=3)$. One PST stated the need to add more serious content and commented: "I was afraid that kids might pay more attention to the fact that they have technology in their hand rather than what the video was telling them... I was wrong."

Danielson (2009) conveyed that when classroom teachers are encouraged to ask themselves questions about their classroom practice, they are better able to connect reflection to practical classroom applications. This reflective practice was echoed in the following sentiment: "This project made me hunger more for technology to be placed in the classroom ... I could see the excitement in the student's eyes and I knew that this is something I definitely wanted to incorporate into my classroom."

\section{Discussion}

According to the results of this research, PSTs' reflections indicated that AR technology has the potential to impact learning experiences in elementary science education. Regardless of grade levels or science content, the use of AR increased student engagement, held student's attention longer than traditional teaching methods, and increased student questioning on scientific concepts.

Cai et al. (2013) contended that the use of AR has the potential to result in more significant learning gains for lower-achieving students than for higher-achieving students. However, it is important to note that in this study, both regular and inclusion students were reported to have performed well on assessments after the use of AR supporting the notion that the use of AR has the potential to break down barriers and differentiate learning for all students regardless of background or disability.

According to Jukes et al. (2010), there is a rapidly growing problem in education today. The problem is that modern students growing up in a digital world do not learn best from teachers using traditional methods of teaching. Educators must be willing to embrace technology in order to prepare our students for the twenty first century and beyond. In fact, research by Chai et al. (2010) emphasized that PSTs who have acquired higher levels of technology are more willing to use technology in the classroom. The International Society for Technology in Education (2008) standard specified that teachers are to advance student learning, creativity, and 
innovation using digital tools and resources. Yet, to use innovative technologies like $\mathrm{AR}$ in classrooms, it is important to recognize and find ways to overcome the challenges described in this study.

According to Pérez-López and Contero (2013), one factor to consider when implementing any new technology is system usability. And, although the prospective teachers highlighted that fact that the Aurasma application was easy to use and effective in supporting the acquisition of scientific knowledge, some noted that there were still obstacles to learning the technology. Another challenge noted in this study was that teachers may be faced with a lack time of time or the motivation to learn new technology skills. These findings reinforce Ertmer and Ottenbreit-Leftwich's (2010) research that states “although knowledge of technology is necessary, it is not enough if teachers do not also feel confident using that knowledge to facilitate student learning" (p. 261). For those who did not grow up immersed in or feel confident in using technology, it is vital that support, time, and training be provided in order to integrate technology and pedagogy effectively into classrooms. Also, teacher preparation programs may want to consider the placement of PSTs into more technically advanced classrooms as some of the mentor teachers noted having limited time to teach science or integrate technology effectively.

Other limitations in this study involved the lack of hardware (iPads) and Internet (Wi-Fi) connectivity in classrooms to implement the Aurasma platform. When technology fails, it can shatter the confidence of the teacher who has invested time and energy into planning the AR activity. For those campuses who cannot afford to purchase individual iPads for students, it may be advantageous to team with other teachers and share devices. If Wi-Fi is scarce, one option would be to tether an iPad to an iPhone in order to get connectivity as needed. The consequence of not having the infrastructure in place will result in students who are not prepared for the world outside the classroom. Schools will need to make a significant investment in the resources (hardware and software) to meet the needs of the twenty first century learner.

Finally, this study indicates that reflection is a vital component to improving teacher practice. More than half of the PSTs implementing AR recognized ways to improve their future use of AR in the classroom. According to Subramaniam (2013), "A look into these practices through a study of the content of preservice teachers' reflections of their early field experiences provides teacher educators a lens into the varied practitioner expertise and practices that their preservice teachers experience, observe, and learn to ground their own future practice of teaching" (p. 1854).

\section{Limitations}

Several limitations exist in this study. This study was limited to one methods course at one university during one semester. Another limitation is that the data are based upon PSTs' perceptions of the use of AR. Neither the students nor the mentor teachers were surveyed. Finally, there were multiple campuses and grade levels in connection with this study making it difficult to generalize the findings. However, 
the PSTs generally reported similar strengths and weaknesses to using AR across campuses and grade levels.

The findings in this study suggest that AR is educationally valuable and engages students. However, the lack of research is a major limiting factor in terms of discussing whether AR meets the needs of all learners.

\section{Conclusion}

Today's students live in a visual world constantly surrounded by images, media, and sound. It has been estimated that within the next 5 years (NMC 2012), AR technology will make it possible to connect science to the lived experiences of students growing up in a digital world. However, Kazlauskas and Robinson (2012) reported, "The caricature of the 21 st century student as an avid consumer of any and all technology does not necessarily transfer to the learning environment" (p. 328). In order to keep up with the ever-changing pace, teachers need to have opportunities to learn and use these exciting and powerful tools. By preparing PSTs to increase student engagement, interest, and achievement through the use of emerging technologies such as AR, the hope is that future generations of students will understand STEM concepts and will pursue careers in a competitive, global work environment.

In the future, additional iterations of this study should go beyond just looking at engagement and motivation and measure additional learning outcomes on the specific concepts being addressed. Furthermore, it would be important to know whether the PSTs involved in this study continued to use AR over time and whether students' interests continued to be held with subsequent use. Also, the value of the PSTs in increasing the technological competency of the mentor teachers should be considered. According to Rogers and Knuth (2000), mentor teachers must begin to view student teachers as a technology resource because of their familiarity and comfort level with the technology.

The research is unique because it looks at how AR can be used to promote engagement, motivation, and student learning from the multiple lenses of soon-to-be classroom teachers. This project, according to one PST, "really pronounced the pros and cons of kids being so technologically advanced and how much effort is truly going to be needed to bridge the ever-growing gap between teachers and their kids!"

\section{References}

Brophy, J. (2008). Developing students' appreciation for what is taught in schools. Educational Psychologist, 43(3), 132-141.

Burmark, L. (2002). Visual literacy: Learn to see, see to learn. Arlington, VA: ASCD.

Cai, S., Chiang, F. K., \& Wang, X. (2013). Using the augmented reality 3D technique for a convex imaging experiment in a physics course. International Journal of Engineering Education, 29(4), 856-865. 
Chai, S. C., Koh, J. H. L., \& Tsai, C. (2010). Facilitating preservice teachers' development of technological, pedagogical, and content knowledge (TPACK). Educational Technology and Society, 13(4), 63-73.

Cheng, K., \& Tsai, C. (2013). Affordances of augmented reality in science learning: Suggestions for future research. Journal of Science Education and Technology, 22(4), 449-462. doi:10.1007/ s10956-012-9405-9.

Christensen, C., Horn, M., \& Johnson, C. (2008). Disrupting class: How disruptive innovation will change the way the world learns. New York: McGraw-Hill.

Courts, B., \& Tucker, J. (2012). Using technology to create a dynamic classroom experience. Journal of College Teaching and Learning, 9(2), 121-128.

Creswell, J. W. (1998). Qualitative inquiry and research design: Choosing among five traditions. Thousand Oaks, CA: Sage.

Danielson, L. M. (2009). Fostering reflection. Educational Leadership, 66(5). http://www.ascd.org/ publications/educational-leadership/feb09/vol66/num05/Fostering-Reflection.aspx.

Dejarnette, N. K. (2012). America's children: Providing early exposure to STEM (science, technology, engineering, and math) initiatives. Education, 133(1), 77-84.

Ditzhazy, H. E., \& Poolsup, S. (2002). Successful integration of technology into the classroom. The Delta Kappa Gamma Bulletin, 68(3), 10-14.

Dunleavy, M., \& Dede, C. (2013). Augmented reality teaching and learning. In J. M. Spector, M. D. Merrill, J. Elen, \& M. J. Bishop (Eds.), The handbook of research on educational communications and technology (4th ed., pp. 735-745). New York: Springer.

Dunleavy, M., Dede, C., \& Mitchell, R. (2009). Affordances and limitations of immersive participatory augmented reality simulations for teaching and learning. Journal of Science Education and Technology, 18(1), 7-22. doi:10.1007/s10956-008-9119-1.

Dunleavy, M., \& Simmons, B. (2011). Assessing learning and identity in augmented reality science games. In L. Annetta \& S. Bronack (Eds.), Serious educational games assessment (pp. 221-240). Rotterdam: Sense Publishers.

Ertmer, P. A., \& Ottenbreit-Leftwich, A. T. (2010). Teacher technology change: How knowledge, beliefs, and culture intersect. Journal of Research on Technology in Education, 42, 255-284.

Freitas, R., \& Campos, P. (2008). SMART: A system of augmented reality for teaching 2nd grade students. In Proceedings of the 22nd British Computer Society Conference on Human-Computer Interaction (HCI 2008, pp. 27-30). Liverpool: Liverpool John Moore's University.

Geroimenko, V. (2014). Augmented reality art: From an emerging technology to a novel creative medium. New York: Springer.

Haymarket Media Group Ltd. (2012). Mills shows brands power of augmented reality. Campaign (UK), $40,21$.

International Society for Technology in Education. (2008). National educational technology standards for teachers. Retrieved from http://www.iste.org/Content/NavigationMenu/NETS/ForTeachers/ NETS_for_Teachers.htm.

Jukes, I., McCain, T., \& Crockett, L. (2010). Understanding the digital generation. Teaching and learning in the new digital landscape. Moorabin: Hawker Brownlow Education.

Kazlauskas, A., \& Robinson, K. (2012). Podcasts are not for everyone. British Journal of Educational Technology, 43(2), 321-330. doi:10.1111/j.1467-8535.2010.01164.x.

Klopfer, E., \& Sheldon, J. (2010). Augmenting your own reality: Student authoring of science-based augmented reality games. New Directions for Youth Development, 128(Winter), 85-94.

Lawless, K. A., \& Pellegrino, J. W. (2007). Professional development in integrating technology into teaching and learning: Knowns, unknowns, and ways to pursue better questions and answers. Review of Educational Research, 77, 575-614.

Lincoln, Y. S., \& Guba, E. G. (1985). Naturalistic inquiry. Beverly Hills, CA: Sage Publications, Inc.

Martín-Gutiérrez, J., Luís Saorín, J., Contero, M., Alcañiz, M., Pérez-López, D. C., \& Ortega, M. (2010). Design and validation of an augmented book for spatial abilities development in engineering students. Computers and Graphics, 34(1), 77-91. doi:10.1016/j.cag.2009.11.003.

Mayer, R. E., \& Gallini, J. K. (1990). When is an illustration worth ten thousand words? Journal of Educational Psychology, 82(4), 715-726.

Medicherla, P. S., Chang, G., \& Morreale, P. (2010). Visualization for increased understanding and learning using augmented reality. In Proceedings of the 11th ACM SIGMM International Conference on Multimedia Information Retrieval (MIR'10), March 29-31, 2010, Philadelphia, PA. 
Moeller, B. \& Reitzes, T. (2011). Integrating technology with student-centered learning. Nellie Mae Education Foundation. http://www.nmefoundation.org/getmedia/befa9751-d8ad-47e9-949dbd649f7c0044/integrating.

National Research Council. (1996). National science education standards. Washington, DC: National Academy Press.

National Research Council. (2012). A framework for K-12 science education: Practices, crosscutting concepts, and core ideas. Committee on a Conceptual Framework for New K-12 Science Education Standards. Board on Science Education, Division of Behavioral and Social Sciences and Education. Washington, DC: The National Academies Press.

National Research Council. (2013). Appendix J: Science, technology, society and the environment. http:// nstahosted.org/pdfs/ngss/20130509/AppendixJ-ScienceTechnologySocietyAndTheEnvironment_0.pdf.

National Science Foundation. (2002). Augmented reality brings dinosaurs into the 21st century. http:// www.nsf.gov/od/lpa/news/02/tip021022.htm\#first.

New Media Consortium, NMC. (2012). The NMC horizon report: 2012 K-12 edition. http://www.nmc. org/publications/2012-horizon-report-k12.

New York Times. (2013, December 8). Who says math has to be boring? http://www.nytimes.com/2013/ 12/08/opinion/sunday/who-says-math-has-to-be-boring.html?pagewanted=all\&_r=0.

Nunez, M. M., Quiros, R. R., Nunez, I. I., Carda, J. B., \& Camahort, E. E. (2008). Collaborative augmented reality for inorganic chemistry education. In 5th WSEAS/IASME International Conference on Engineering Education (EE'08), Heraklion, Greece, July 22-24, 2008 (pp. 271-277).

Oblinger, D., \& Oblinger, J. (2005). Is it age or IT: First steps toward understanding the Net generation. In D. G. Oblinger \& J. L. Oblinger (Eds.), Educating the net generation (pp. 2.1-2.20). http://www. educause.edu/research-and-publications/books/educating-net-generation/it-age-or-it-first-steps-towardunderstanding-net-generation.

Olsson, T., \& Salo, M. (2012). Narratives of satisfying and unsatisfying experiences of current mobile augmented reality applications. In Proceedings of CHI' 12, Austin, TX, USA (pp. 2779-2788). New York: ACM Press.

Peeck, J. (1993). Increasing picture effects in learning from illustrated text. Learning and Instruction, 3(3), 227-238.

Pérez-López, D., \& Contero, M. (2013). Delivering educational multimedia contents through an augmented reality application: A case study on its impact on knowledge acquisition and retention. Turkish Online Journal of Educational Technology, 12(4), 19-28.

Powell, W., \& Kusuma-Powell, O. (2011). How to teach now: Five keys to personalized learning in the global classroom. Alexandria, VA: ASCD.

Prensky, M. (2001). Digital natives, digital immigrants. On the Horizon, 9(5), 1-6.

Prensky, M. (2013). Time-travel as punishment. http://marcprensky.com/writing/Prensky-Time_Travel_ as_Punishment-EDTECH-Jan-Feb\%202013-FINAL.pdf.

Rogers, P. L. (2000). Barriers to adopting emerging technologies in education. Journal of Educational Computing Research, 22(4), 455-472.

Rogers, G., \& Knuth, R. (2000). Critical issue: Providing professional development for effective technology use. North Central Regional Educational Laboratory. http://www.ncrel.org/sdrs/areas/ issues/methods/technlgy/te1000.htm.

Shelton, B. E., \& Hedley, N. R. (2004). Exploring a cognitive basis for learning spatial relationships with augmented reality. Technology, Instruction, Cognition and Learning, 1(4), 323-357.

Squire, K., \& Klopfer, E. (2007). Augmented reality simulations on handheld computers. Journal of the Learning Sciences, 16(3), 371-413.

Subramaniam, K. (2013). Examining the content of preservice teachers' reflections of early field experiences. Research in Science Education, 43(5), 1851-1872. doi:10.1007/s11165-012-9337-7.

Sumadio, D. D., \& Rambli, D. A. R. (2010). Preliminary evaluation on user acceptance of the augmented reality use for education. In Paper Presented at the 2010 Second IEEE International Conference on Computer Engineering and Applications, Bali, Indonesia.

Tarng, W., \& Ou, K. L. (2012). A study of campus butterfly ecology learning system based on augmented reality and mobile learning. In 2012 IEEE Seventh International Conference on Wireless, Mobile and Ubiquitous Technology in Education (pp. 62-66).

Tian, K. E., Endo, M., Urata, M., Mouri, K., \& Yasuda, T. (2013). Ubiquitous augmented reality mobile learning system for supporting moon observation. In Proceedings of the International Conference on Business and Information, September 24-26, 2013. http://ibac-conference.org/ISS\%20\&\% 20MLB\%202013/Papers/ISS\%202013/A3260.pdf. 
U.S. Department of Education Office of Educational Technology. (2010). Transforming American education, learning powered by technology: National education technology plan 2010. http://www. ed.gov/technology/netp-2010.

Wenger, E., Trayner, B., \& de Laat, M. (2011). Promoting and assessing value creation in communities and networks: A conceptual framework, Rapport 18. Ruud de Moor Centrum, Open University of the Netherlands.

Wojciechowski, R., \& Cellary, W. (2013). Evaluation of learners' attitude toward learning in ARIES augmented reality environments. Computers and Education, 68, 570-585. doi:10.1016/j.compedu. 2013.02.014.

Yin, R. K. (2003). Case study research: Design and methods (3rd ed.). Thousand Oaks, CA: Sage.

Yoon, S. A., \& Wang, J. (2014). Making the invisible visible in science museums through augmented reality devices. Techtrends: Linking Research and Practice to Improve Learning, 58(1), 49-55. doi:10.1007/s11528-013-0720-7.

Julie A. Delello Assistant Professor in the College of Education and Psychology, The University of Texas at Tyler. Dr. Delello is also a Faculty Fellow for Academic Innovation at The Center for Teaching Excellence and Innovation. Dr. Delello has more than 20 years of experience in K-16 education as a practicing teacher and an administrator. She received her Ph.D. in Curriculum and Instruction with a specialization in science and technology from Texas A\&M University. Her scholarly publications include topics on millennial learners, disability and family studies, visual media technologies, STEM education applications, and social media platforms for authentic learning. She helped to design virtual science museums in conjunction with The Chinese Academy of Sciences, Computer Network Information Center in Beijing, China. In addition, she has won several grants and teaching awards including a National Science Foundation Grant, the Golden Apple Educator Award, the 2012 University of Texas at TylerKappa Delta Pi Teacher of the Year award, and the 2013-2014 Jack and Dorothy Fay White Fellowship for Teaching Excellence Award. She was also the invited guest speaker at the United States Department of State Eleventh Annual Joint U.S.-China Joint Science and Technology Commission Meeting on the efforts of expanding the scientific and educational ties between the U.S. and China. In addition, she is a member of several national organizations and serves on several city-wide and campus committees. 